\title{
Philosophy of History in the 2017 Jakarta Gubernatorial Election An Applied Philosophical Study in the Light of Hegelian Philosophy of History
}

\author{
Dr. Andreas Yumarma \\ President University, Faculty of Business \\ Kota Jababeka, Cikarang, Bekasi 17550 \\ Indonesia
}

\begin{abstract}
This paper investigates the 2017 Jakarta gubernatorial election showing a historical dynamics that generates the chosen local leaders. The objective of research is to examine the movers of the dynamics of election and its pattern of change influencing the election. The method of research is an applied philosophical approach in the light of Hegelian philosophy of history. The result of the research is philosophical thoughts to anticipate the problem potential of the 171 simultaneous local elections in 2018 and the 2019 presidential election.
\end{abstract}

Keywords: The 2017 Jakarta gubernatorial election, mover of history, Hegelian philosophy of history, pattern of historical dynamics

\section{Introduction}

Among the 101 simultaneous local elections throughout Indonesia on $15^{\text {th }}$ of February 2017, the Jakarta gubernatorial election gets special attention by Indonesian people, national and international mass media. It takes place due to some reasons. Firstly, Jakarta is the capital of Indonesia. As the capital of the country, Jakarta has nuance of both local and national as well as international at the same time. Secondly, the intense involvement of the Indonesian three top national political party leaders (Charlotte Setijadi, Deasy Simandjuntak, and Dirk Tomsa, 2016:1) like Megawati, Prabowo Subianto, and Susilo Bambang Yudhoyono reflects the importance of the 2017 Jakarta gubernatorial election (Indra Budiari, 2017). Thirdly, Jakarta is Indonesia's center for politics, economics and culture (Abdul Hamid, 2014:86). For that reason, Jakarta functions as a parameter of the Indonesian politics, economics and cultural Development. Fourthly, the result of the Jakarta gubernatorial election is very influential to the dynamic of the further 171 local elections in 2018 and the legislative and presidential election in 2019.That is why the 2017 Jakarta gubernatorial election feels like presidential election.

The complexity of Jakarta contains various problems and challenges. There are many various ethnics, cultures and religions. Besides them, the increase of residents' number, congestion in transportation, annual flood, housing, urbanization, poverty, gap between the rich and the poor, crime and unemployment are daily public issues which are waiting for resolutions. In such a situation the gubernatorial election is conducted to choose the expected local leaders that meet their expectation. Societal condition, problems, track-record of the candidates and their programs become materials for campaigning and winning the race (Elfira Catherin et.al., 2017:5-9). This research, therefore, focuses on the critical analysis of the 2017 Jakarta gubernatorial election in the light of Hegelian philosophy of history. The basic questions of the research are which ones are the movers of historical dynamics in the 2017 Jakarta gubernatorial election and how do the patterns of change and continuity take place in the gubernatorial election?

With regard to the questions above, this research tries to discover and examine factors of force and the electoral dynamics during candidacy, campaign and election using the Hegelian philosophy of history. Its purpose is to examine the principles of the mover of history, pattern of historical change and dynamics that exist in the election. Philosophical thoughts on the principles of the mover of history and recommendations for the democracy education are the result of this research. They are very important for the citizens, government, public policy making and societal order in the successive elections.

\section{Method of study}


This research uses the method of Hegelian Philosophy of History to shed a light on the dynamics, forces and pattern of change as well as the continuity elements in the 2017 Jakarta Gubernatorial Election. The result of polling surveys, library research, Focus Group Discussions (FGDs), direct observation of social media enrich the necessary data of the election.

Characteristics of the Hegelian philosophy of history is the terms of subjective spirit, objective spirit, and absolute spirit that are used to analyze the movers of history. Those spirits describe the principles that determine the course of history. The subjective spirit is an individual ambition and desire as the mover of history. It is opposite from objective spirit. Unlike the subjective spirit, the objective spirit implies to the public expectation and desire. Both of them are in tension of the one against another. However the absolute spirit as a new synthesis power embraces all of them.

Those spirits work in a certain pattern which is called dialectics. The Hegelian dialectics` is characterized by the dynamics of thesis-antithesis and synthesis. This dialectics takes place in such a way so that the subjective spirit functions as a thesis. The objective spirit as antithesis, and then the absolute spirit works as a new synthesis among them. The dialectical dynamics is very unique in the Hegelian philosophy of history. We use them as tool of the critical analysis on the examination of the 2017 Jakarta gubernatorial election.

\section{The Hegelian Philosophy of History.}

To understand the Hegelian philosophy of history, we have to discuss the general sense of the philosophy of history. Philosophy of history basically is a discipline of knowledge which deals with speculative theory of history, the nature of history consisting of the past-now and future, the meaning of historical occurrences or figures and certain principles or historical law in the continuity and discontinuity process. Philosophy of history should not be confused with history of philosophy. The distinction among them can be seen from the formal object, the material object and the scope of the philosophy of history. The formal object of the philosophy of history is the methodology which is analytic and speculative theory, hermeneutics, narrative explanatory, historiography and teleology. Philosophy of history uses them to examine the past facts, recent occurrences, figures, various backgrounds and principles in the process of history. The material object of the philosophy of history is the past facts, the on-going historical occurrences, figures, causality connection, historiography, the historical dynamics of the past, now and future. The analysis of this material object produces principles, pattern of historical dynamics, fundamental thoughts, meaning of events/figures and the significance of historical facts.

The scope of the philosophy of history includes facts, the interpretation of figures, events and human history. K. Lowith, as quoted by Coll, perceives the philosophy of history as an attempt to understand the meaning of historical actions and sufferings. It is nothing other than a principle of systematic interpretation of universal history through historical events and consequences which are united and directed towards an ultimate meaning (Gabriel Amengual Coll, 2015:40).

In the Hegelian philosophy of History, Hegel emphasizes the absolute spirit as the principle of the mover of history. This absolute spirit can be understood as soul, reason and self-awareness implying to perfection, totality and full self-awareness. It moves in the dynamics of history by means of the freedom development towards its culmination in the self-awareness. The absolute spirit is not the subject but it is a principle of historical dynamics. Human beings have freedom and will. Human will is limited to know the divine. The absolute is manifested in divine and human will. It involves intellect, soul, mind and thought. It starts from the subconscious spirit coming to the spirit which realizes itself and ends to the awareness of all individuals and society. The process of the spirit is essentially progress (Hegel 1970:70; Gabriel Amengual Coll, 2015:38). The absolute spirit is the end of the dynamic process of the subjective spirit and the objective spirit. The absolute spirit is also understood as perfection which is full of awareness that becomes the direction of the dialectic process. History, therefore, is the process of realization of the spirit. Philosophy of history in Hegel, accordingly, is no other than the unfolding of human freedom.

The pattern of historical dynamics takes place in the dialectic of thesis, antithesis and synthesis. It can be compared to the dynamics of being, non-being and becoming. The course of history proceeds from subjective spirit, objective spirit towards absolute spirit. The objective spirit functions as guidance of action among individuals and communities. Tension of thesis versus antithesis generates a synthesis. Furthermore the synthesis then will also function as a new thesis which will be negated by antithesis and it then produces another new synthesis. The spiral pattern of history moves towards the absolute spirit. However this process is also influenced by the absolute spirit 
as the finality cause. This absolute spirit plays a role as the final destination. According to Hegel, the end or goal of history is the actualization of freedom in the life of the modern nation-state (David Duquette, 2015). The philosophy of history, accordingly, is the conclusion of the objective spirit and the steps towards the absolute spirit (Gabriel Amengual Coll, 2015:51).

\section{The 2017 Jakarta Gubernatorial Election.}

The 2017 Jakarta Gubernatorial election is one of the routine festival of democracy held every 5 years. The 2017 Jakarta Gubernatorial election belongs to the regions having potential of societal conflicts during the election, such as in Papua and Aceh. The General Election Commission (KPU) has a central role in making regulations to be applied in the election. The basis of regulations by KPU is the General Election Law (UU KPU).

With refer to this General Election Law, the requirements, procedure and phases of the election are prepared by the General Election Commission (KPU) and Local Election Comission (KPUD) in cooperation with other relevant institutions and organizations. They constitutes the electoral guidelines, the electoral watch agencies and participation of citizens. The timeline of the 2017 Jakarta gubernatorial election (www.kpujakarta.go.id) is as follows:

1. Submission of the requirements of the independent candidate is from $3^{\text {rd }}$ to $8^{\text {th }}$ of August 2016 .

2. Registration of the candidate pair is from $21^{\text {st }}$ to $23^{\text {rd }}$ of September 2016

3. The candidate pair verification is from $21^{\text {st }}$ of September 2016 to $5^{\text {th }}$ of October 2016

4. Notification of the candidate pair is on $24^{\text {th }}$ of October 3016

5. Decree of the number of the candidate pair is on $25^{\text {th }}$ of October 2016

6. Resolution on the candidacy conflict is from $24^{\text {th }}$ of October 2016 to $17^{\text {th }}$ of January 2017

7. Campaign is from $28^{\text {th }}$ of October 2016 to $11^{\text {th }}$ February 2017

8. Cooling off period and the cleaning of the visual tool is from $12^{\text {th }}$ to $14^{\text {th }}$ of February 2017

9. Voting and counting the votes are $15^{\text {th }}$ of February 2017

10. The vote recapitulation is from 16th of February 2017to $27^{\text {th }}$ of February 2017

11. Decree of the chosen candidates is on $11^{\text {th }}$ to 13 rd of March 2017

12. Conflict of the election result (Follow the constitution court schedule)

13. Declaration of the chosen candidate pair after the result of constitutional court (Maximum is in three days after the result of constitutional court)

The timeline above reflects some important phases and dynamics of the 2017 Jakarta Gubernatorial election.Among them, there are some phases that should get a special attention to discover the movers of history and its patterns of historical change in the election.

\subsection{Candidates' Registration.}

There are three pairs of candidate registering themselves in the 2017 Jakarta gubernatorial election (Selvi Aprilianti, 2017:3). Those candidates are Agus Harimurti Yudhoyono-Sylviana Murni known as Agus-Sylvi, Basuki Tjahaja Purnama-Djarot Saiful Hidajat known as Ahok-Djarot, and Anies Rasyid Baswedan and Sandiaga Salahuddin Uno known as Anies-Sandi.

The pair of Agus-Sylvi is supported by political party of Democrat, PKB, PAN and PPP. Agus Harimurti is the eldest son of the former President Susilo Bambang Yudhoyono. He got the rank of major in his career in the army. He left his career in army under the shadow of his father's design. His candidacy to compete in the gubernatorial election makes a surprise, because he comes into the competition of election without any political experience. The role of Susilo Bambang Yudhoyono and hist party has significant influential power in the candidacy of Agus-sylvi. The second pair of Ahok-Djarot is supported by political party of PDIP, Nasdem, Golkar, and Hanura. Ahok is the incumbent governor. Ahok becomes the governor when Jokowi is elected as President in 2014. He has got political experience as the member of the regional parliament in 2004. His political career is built on an anti-corruption platform. There are more than one million citizens who support Ahok from the independent candidate before the candidacy registration to KPU. Ahok, however, prefers to be supported by political parties at the last time of registration. The role of Megawati and her political party of PDIP is the dominant power in the process of the AhokDjarot's candidacy.

The third pair of Anies-Sandi is supported by Polical party of Gerindra and that of PKS. Anies is the former minister of education in the cabinet of Jokowi in 2014. His termination as the minister of Culture and Education takes place 
in the 2016 cabinet reshuffle (Gede Alit Purtra, 2017:9). Anies is proposed as the candidate of governor to Gerindra party by Jusuf Kalla on the last moments of registration .His pair as vice governor is Sandi, a super rich businessman. The role of Jusuf Kalla and Prabowo Subianto are the dominant power in the candidacy registration of Anies-Sandi.

The candidates' registration is a starting point that they are formally recognized as candidates of governor and vice governor in the further process of election. The roles of political parties, supporters, and mass media have worked from the very beginning. They influence the political dynamics, image building, campaign, strategy and maneuvers, as well as the result of competition in the 2017 Jakarta gubernatorial election.

\subsection{Campaign period.}

The campaign period is the moments in which candidates and supporters endeavor to win the heart of citizens. The campaign is very important for some reasons. Firstly, the campaign is a media of the candidate and supporters to communicate the figure, vision and mission of the candidate. Through the campaign people will know more about the candidate, his character and other positive attributes of the candidate (Selvi Aprilianti, 2017:4). Secondly, campaign is media to influence people to give their votes for the candidate. The campaign will influence the electability of the candidate. The candidates and supporters sometimes undertake excessive maneuvers and actions in order to influence voters. They cause tension, constraint, fraud, anxiety and societal frictions.

Generally there are several kinds of campaign. They are positive campaign, negative campaign, white campaign and black campaign. The positive campaign focuses on the strength of the candidate included expertise, vision, mission and his good characters. In other words, the campaign is based on the facts of truth about candidates and their strengths. In contrast to this, there is a campaign which is called negative campaign. The negative campaign focuses on the weakness of the competitors. It attacks the shortcomings of the competitors using evidences and facts. Unlike the negative campaign, the campaign which is called the white campaign is sort of campaign using all various efforts to build trust feeling of the citizens to the candidate. The most crucial campaign is the black campaign. This sort of campaign continuously focuses on attacking the competitors without any accurate data, disinformation or even manipulating the data. Such a campaign spreads hoaxes and fake news to attack the candidate competitors. The black campaign uses all means that can bring about violence, fears and even chaotic and anarchic societal situation. For these reasons, the campaign regulatory should not give any loophole for such a campaign.

Political parties' leaders and their affiliated organizations support the candidates in a political coalition. Coalition of the political parties take important roles in the strategy of campaign and in influencing the citizens' decision. They utilize their political organizations, societal elements and power to win the competition. However the candidates' figure is an important factor in getting votes. For that reason, the supporters make favorable image and branding of candidate in order to make them become icons that draw people's attention. An image of the anti-corruption figure, for instance, is created because the corruption is still the main issue in both Jakarta and Indonesia.

To win the competition, the religious and ethnic sentiments are engineered in such a way so that the campaign maneuvers are done to defeat the incumbent candidate who is Chinese descent and Christian. Such a maneuver takes place in both the first round of election and the second round of election. The culmination of it takes place at the end of campaign moments when the dead corps of the one of the incumbent governor's supporters was rejected and not allowed to be prayed in the mosque. Mass media also spread both positive information and fake news or hoaxes to the citizens. The various responses of citizens can be seen from their choices. The citizens" choices reflect the level of citizens' maturity. Intimidation and inclusion have been parts of the campaign strategies since the previous election (Vera Almeyer, 2014:121-132). Coming closer to the end of campaign, intimidation takes place to the candidates and supporters of Ahok-Djarot. It is ironic of democracy that some citizens still love to be lied with bombastic expressions, fallacy and sarcastic disinformation. The double minority status of Ahok as Chinese descent and Christian becomes ammunitions for the competitor candidates to get rude attacks during campaign period.

\subsection{Cooling off period.}

Cooling off period in the first round of election is from 12th to 14th of February 2017. They clean banners, pamphlets and propagandas along the street. No mass mobilizations are allowed during the cooling off period. However some tricky activities take place to influence the voters. For example, the candidate attends the wedding 
in the cooling off period so that the candidate got highlight in the newspaper and social media. Cooling off period of the second round of election is from $15^{\text {th }}$ of April to $19^{\text {th }}$ of April 2017. Even though there is no campaign but activities of candidates are subjects of news in the online social media and television. Hidden campaign takes place in such a way using loopholes of the electoral regulation.

Money politics are used to be done in this period. Money can be distributed in the very early morning before they give their votes. Money politics can happen because of tough competition among the candidates (Andrean Winata,2017: 12).

The excessive desire to win and lack of confidence with their resource and capability bring about dirty ways in winning the competition. They give money or whatever people need so that citizens give their votes for their candidates. According to DKI Jakarta Bawaslu and North Jakarta Panwaslu, there are 20 cases concerning money politics, gratification of basic necessities, giving stuff (sembako), gift and public facilities in the 2017 Jakarta gubernatorial election (see Andreas Winata, 2017: 13)

\subsection{Result of the election.}

The result of the first round of the 2017 Jakarta gubernatorial election according to official recapitulation of KPU (KPU, 26 February 2016) is as the following:

The Agus-Sylvi pair gets 937.955 votes (17.05\%)

The Ahok-Djarotpair gets 2.364 .577 votes $(42.91 \%)$

The Anies-Sandipair gets 2.197 .333 votes $(40.05 \%)$

The level of the citizens' participation in this first round of the 2017 gubernatorial election is $75.75 \%$.The above result of the first round of election reflects that the pair of Agus-Silvy had been defeated and eliminated in this first round. Since Jakarta is special region, so the winner of the 2017 Jakarta gubernatorial election must get $50 \%$ plus one. There is no candidate which achieves the required number of vote to be the winner. For this reason the second round of the election must be conducted in order to get the winner of the 2017 Jakarta gubernatorial election. The participants of the second round of the 2017 Jakarta gubernatorial election is the pairs of Ahok- Djarot and AniesSandi.

The time line of the second round of the 2017 Jakarta gubernatorial election is as the following:

1. Notification of the Second round of the election of Governor and Vice governor is 4th of March 2017

2. Recapitulation of the voters' list is from 5th of March 2017 to 19th of April 2017

3. Socialization is from 4th of March 2017 to 15th of April 2017

4. Campaign period is from 6th to 15 th of April 2017

5. The Sharpening of the vision and mission is from 6th to 15th of April 2017

6. Cooling off period and cleaning of the visual tool is from 16th to 18th of April 2017

7. Voting and counting of the votes is on19th of April 2017

8. Vote recapitulation is from 20th of April 2017 to 1st of May 2017

9. Notification candidates without any dispute is from 5th to 6th of May 2017

10. Notification of the winning candidate pair after the Constitutional Court's Decree (Maximum Is Three Days after The Constitutional Court's Decision)

Two public debates of the candidates are conducted on $13^{\text {th }}$ of January 2017 with Najwa as moderator and 12th of April 2017 with Ari Kusno as moderator. Both of them are aired by television stations. The Interesting dynamics takes place during the campaign until the day of the election. The mass mobilization by hardline muslims (FPI) and the coalition of Gerindra and PKS concerning the blasphemy case of Ahok also addresses the position of Jokowi as President. Such a mass mobilization colors the atmosphere of the second round of election. This second round of election gets higher participation from the citizens compared to the first round of election. It is enough to say that the second direct electoral experience is followed by higher participation of people.

The result of the second round of the 2017 Jakarta gubernatorial election is as the following: The pair of AniesSandi as the winner gets 3.240 .987 votes $(57.95 \%)$. The incumbent Ahok-Djarot gets 2.350.366 votes (42.05\%). The citizens' participation in this second round of election is $78 \%$. The above result reflects that the Anies-Sandi pair wins the 2017 Jakarta gubernatorial election. The installation of the new governor is conducted on Monday, $16^{\text {th }}$ of October 2017. The dynamics of the 2017 Jakarta gubernatorial campaign and election leaves societal frictions and hurt feeling among the citizens that must be reconciled and recovered after the gubernatorial installation. 


\section{The movers of history in the 2017 Jakarta gubernatorial election.}

The dynamics of election and its process reflect some factors that becomes the movers of the history in the 2017 Jakarta gubernatorial election. Those movers of history are law, human freedom, Identity politics and social media, religious and ethnic sentiments and divine providence.

\subsection{The law as the mover of history.}

Adorno in his critique to Hegel considers the philosophy of law and philosophy of universal history as intertwined in the course of history (Gabriel Amengual Coll, 2015:37-58). Regarding the law as the mover of history, the Indonesian constitution obliges Indonesian government and people to undertake election as the expression of democracy. The constitution generates General election Law, KPU Law, regional regulations and KPU regulations that sustain the course of election history. They influence the process, phases and electoral timeline/ schedule.

The content of the law is the regulation to protect and channel people's aspirations, citizens' rights and interest. The electoral law becomes arena, scope and space of the dynamic of process, frame of campaign and election. Moreover law also plays an important role as a frame and guideline in the process of election. The electoral law obligates the government to conduct the election in transparent, fair and honest way. There is a pattern of dynamics between law, ambition to win, and electoral practice. Law functions as thesis; and ambition to win as antithesis. The electoral practice is a synthesis emerging from the tensions among them. The laws function as the foundation and framework of the electoral practice. The law works as a thesis of the election existence. The ambition of candidates to win functions as anti-thesis in the maneuvers that tend to get loopholes or even to break the law. The electoral practice of the 2017 Jakarta gubernatorial election and what takes place in the election function as a synthesis which embraces the ambition to win and the law regulating the process.

\subsection{Human Freedom as the principle of the mover of history.}

Unitary and teleological process absorb individuals as the means to achieve the end sought (Gabriel Amengual Coll, 2015:38). The principle of history is the progress of reason and human freedom. Citizens give their votes based on reasonable considerations that are actualized in the choice of giving their votes. In other words, the election is an expression of human freedom to choose their leader. The principle of the mover of history in the election is the fullness of humanity in which human reason develops in a full way and it becomes the actualization of human freedom. For that reason, election and democracy should become people's celebration with the participation of the maximum number of people.

Unlike the ideal one, people's choice is sometimes engineered by intimidation, money politics, societal conflicts, anxiety atmosphere and scaring threats. The principles of "being opened or transparent, fair/just and honest" do not always work in perfect way. For this reason the election watch agencies have to work effectively so that the election produces the legitimate leader.

\subsection{Political Identity and Social Media Power.}

Jakarta is the mirror of Indonesia consists of many ethnics and diverse religions. There are 714 diverse ethnics in Indonesia. Most of the ethnics in Indonesia also exist in Jakarta. Some supporters and teams candidates use such a fact to do the campaign to win the heart of people. They engineered the identity politics to create horizontal tensions, conflicts with neighbors and societal frictions to delegitimize the incumbent position as the candidate. This political identity does not work without any influence of social media. Regarding the 2017 Jakarta gubernatorial election, Ahok has the double minority status as Chinese descent and Christian. The black campaign using political identity and social media brings him to the case of blasphemy. The massive demonstrations from the Islamic hard line groups during that period also influence the emotion and sentiment of people to choose. The excessive usage of social media brings Ahok and the uploader of his speech to prison. Behind all of these phenomena there is a tension power between nationalistic wings and the right. They work like thesis vs anti-thesis. The ethnic groups, religions, mass organizations and social media have been framed in the identity politics. This tension generates the stronger one become the winner in the 2017 Jakarta gubernatorial election. It produces a huge homework for reuniting the people and reconciliation.

\subsection{Divine providence as the mover of history.}


Subjective spirit in the election is the desires of candidates to be governor and vice governor. Inside them there are wills to power, money, position and facilities. Money as mover of subjective spirit can be seen in the practice of money politics (Ariel Natasha Gunawan,et.al, 2017).

Bad perception of politics functions as mirror of their dirty political practice. There are some political motivations that sometimes they use any means so that politics is perceived as dirty one. The figures of bad politicians being arrested by the corruption eradication commission (KPK) strengthen such a perception.

The objective spirit is the divine legitimation. Ahok states that the power comes from God. He has to face the court process during the campaign period until to be put in prison for the blasphemy case cannot be separated from religious belief. Figure of the candidate as the mover of subjective spirit can be seen in self-image building by candidates. The subjective spirit influences the black campaign that exists in the process of political democracy (Luisa et al, 2017:1-15). Objective spirit is seen track record, law and regulation, image building as victim, and social media.

On the other sides, Anies in the public debate also states that God can change the heart of people to choose their leaders. Using religion as the argument in campaign is also part of factors on how we can understand the divine factors in the election. Absolute spirit expresses common public expectation, realism, rationality and critical considerations. The belief of majority of people that everything can happen with the permission of God places the divine providence as the mover of history. However sometime it is difficult to make distinction between God's will and the product of human freedom.

\section{Conclusion.}

As conclusion this research discovers some historical movers that become the influencing principles in the 2017 Jakarta Gubernatorial election. Those movers are: (1) Law as the historical mover. The legal power influences the historical dynamics, phases, timeline and agencies in the election. (2) Human freedom which expressed in the will to power by individual and political parties. There is public expectation and individual freedom that are engineered in the campaign and decision of giving votes. The will to power is motivated by the prestigious position and its authorities, privileges, income and facilities. Besides, the will to power is also based on various individual motifs. Among them are noble desires to give contributions to common interest and country, economic and social welfare. (3) The identity politics and social media that have been successful in stimulating the sentiments and emotion of primordial and groups' interests. Ethnical and religious feeling and fear of the public conflicts have influenced the choices. The online social media power takes a significant role in creating news. Political parties' power in coalition also makes maneuvers that influence the mood of the voters. (4) Divine providence as the historical mover is used to legitimize their leadership. People and the government learn how the religious belief influences the human will to give the votes to worthy candidate.

The pattern of historical dynamic is (1) Thesis-antithesis-synthesis 2) subjective expectation, objective expectation and absolute expectation 3) right wing-left and nationalism. The dynamics between the nationalistic and Islamic politicians works during the process of election. Whatever its dynamics, finally all the people have to accept the chosen leaders to serve people's interests and to make reconciliation for the hurt feeling taken place during the whole process of the election.

As recommendation, government and society should learn not to use the black campaign, the ethnic identity and religious maneuvers that demand very expensive social and economic costs. However they all become the movers of history in the 2017 Jakarta gubernatorial election. It takes long time to recover the hurt feelings of societal groups and to make societal reconciliation or traumatic healing. To anticipate the other simultaneous local election 2018 and the 2019 presidential election, the government, KPU and all parties should educate people's maturity in the usage of social media, citizens' critical thinking and the aspiration of the noble spirit of constitution. The destructive pattern of historical movers has to be prevented and anticipated using the power of legal and regulatory instruments.

\section{Bibliography}

ABDUL HAMID, (2014): Jokowi's population in the 2012 in the 2012 Jakarta Gubernatorial election, Journal of Current Southeast Asian Affairs 33(1):85-109. 
ANDREAN WINATA, (2017):Money Politics in Jakarta Gubernatorial Election 2017; Should We adapt to Digital Democracy. Final Project of State Philosophy and Citizenship, Cikarang-Bekasi: President University (unpublished).

ANISA MUTHI'AH RAHIMAH, (2017):The Role of Social Media towards Ahok Alleged Blasphemy Case and its Implies to Indonesia Society, Final Project of State Philosophy and Citizenship, Cikarang-Bekasi: President University (unpublished).

INDRA BUDIARI, (2017):Jakarta gubernatorial election most anticipated event on Wednesday. Retrieved on February 25, 2017 from http://www.thejakartapost.com/news/2017/02/14/jakarta-gubernatorial-electionmost-anticipated-event-on-wednesday.html

CHARLOTTE SETIJADI, DEASY SIMANDJUNTAK, AND DIRK TOMSA, (2016):Candidates, Coalitions and Prospects for the 2017 Jakarta Gubernatorial Election, ISEAS (Perspective) 57: 1-7.

COLL, GABRIEL AMENGUAL, (2015): Philosophy of History as Theodicy, Catalan Social Sciences Review 5, Seccio de Filosofia I Sciences socials, IEC, Barcelona.

DUQUETTE, DAVID (2015):Georg Wilhelm Friedrich Hegel: Philosophy of History, http://www.oxfordbibliographies.com/view/document/obo-9780195396577/obo-97801953965770133.xml. Retrieved on 10-03-2017

ELFIRA CATHERIN ET. AL., (2017):Competition in Simultaneous Election "The Strategy at Jakarta Local Election”, Group Project Report of State Philosophy and Citizenship, President University.

GEDE ALIT PUTRA,(2017):Jakarta's 2017 Gubernatorial Elections: More than Just Politics More than Just Economy, Final Project of State Philosophy and Citizenship, Cikarang-Bekasi: President University (unpublished).

ARIEL NATASHA GUNAWAN,ET.AL, 2017:Money Politic in Jakarta Gubernatorial Election 2017, Group Project Report of State Philosophy and Citizenship, President University.

LUISA ET. AL., (2017):The Existence and the Effect of Black campaign in Political Democracy: Jakarta Gubernatorial Election 2017, Group Project Report of State Philosophy and Citizenship, President University.

SELVI APRILIANTI,(2017):The Existence of Creative Campaign in Jakarta Gubernatorial Second Round Election 2017, Final Project of State Philosophy and Citizenship, Cikarang-Bekasi: President University (unpublished).

VERA ALMEYER, (2014): Intimidation versus Inclusion: New Strategis in Indonesian Election Campagning, ASEAS-Austrian Journal of South-East Asian Studies, 7(1), 121-132.

VIVIEN, (2017):The Existence and the Effect of Attacking Campaign in Political Democracy: Jakarta Gubernatorial Election 2017, Final Project of State Philosophy and Citizenship, Cikarang-Bekasi: President University (unpublished). 